\title{
MENINGKATKAN KEMAMPUAN BERBICARA ANAK MELALUI MEDIA BIG BOOK
}

\author{
Riska Sulistyawati ${ }^{1}$ Z Zahrina Amelia ${ }^{1}$ \\ ${ }^{1}$ Program Studi Pendidikan Guru Pendidikan Anak Usia Dini, Fakultas Psikologi dan Pendidikan, \\ Universitas Al Azhar Indonesia, Jalan Sisingamangaraja Kebayoran baru, Jakarta Selatan 12110 \\ Penulis untuk Korespondensi/ E-mail: zahrina.amelia@uai.ac.id
}

\begin{abstract}
Abstrak - Penelitian ini bertujuan untuk mengetahui bagaimana meningkatkan kemampuan berbicara anak melalui media big book untuk anak usia 5-6 tahun. Penelitian ini merupakan penelitian tindakan kelas (PTK) yang menggunakan model Kemmis dan Mc Taggart. Subjek penelitian ini adalah 25 anak, yang terdiri dari 11 anak laki-laki dan 14 anak perempuan. Teknik pengumpulan data yang digunakan dalam penelitian ini adalah observasi kemampuan berbicara anak melalui media big book, aktivitas guru dan anak serta dokumentasi. Teknik analisis data yang digunakan pada penelitian ini adalah deskriptif kualitatif. Berdasarkan hasil penelitian diketahui bahwa terdapat peningkatan dalam kemampuan berbicara anak melalui media big book. Hal ini diketahui dari rata-rata anak yang mendapat skor 3 pada setiap indikator yaitu indikator berkomunikasi secara lisan (menceritakan kembali) siklus I sebesar 0\% dan siklus II sebesar 90\% artinya terdapat peningkatan sebesar 90\%. Pada indikator menyusun kalimat sederhana secara terstruktur (SPOK) siklus I sebesar 0\% dan siklus II sebesar $85 \%$ artinya terdapat peningkatan sebesar $85 \%$ dan pada indikator melanjutkan sebagian cerita siklus I $0 \%$ dan siklus II sebesar 95\% artinya terdapat peningkatan sebesar 95\%. Pencapaian di siklus II sudah melebihi indikator keberhasilan yang telah ditentukan yaitu sebesar 75\%. Berdasarkan hasil penelitian dapat disimpulkan bahwa media big book dapat meningkatkan kemampuan bericara anak usia 5-6 tahun. Peningkatan terjadi, dikarenakan dalam bercerita dengan menggunakan big book yang sebelumnya belum pernah diterapkan di sekolah tersebut, big book karakteristik khusus yang penuh warna-warni, gambar yang menarik, maupun kata yang dapat diulang-ulang, mempunyai plot yang mudah ditebak.
\end{abstract}

Kata Kunci: Berbicara, Media Big book, Anak Usia 5 - 6 Tahun.

Abstract - This research is aimed to find out how to improve children's speaking ability through the big book media for children aged 5-6 years. This research is a Classroom Action Research (CAR) using the Kemmis and Mc Taggart models. The subjects of this research were 25 children, consisting of 11 boys and 14 girls. Data collection techniques used in this research were the observation of children's speaking ability through the big book media, teacher and children's activities and also documentation. The data analysis technique used in this research was descriptive qualitative. Based on the results of the research note that there is an improvement in the children's speaking ability through the big book media. This is known from the average children who gets a score of 3 on each indicator namely the indicator of verbally communicating (retelling) cycle I by $0 \%$ and cycle II by $90 \%$ meaning there is an increase of $90 \%$. The indicators compile simple sentences in a structured manner (SPOK) cycle I by $0 \%$ and cycle II by $85 \%$ it means that there is an improvement of $85 \%$ and the indicator continues part of the story cycle I 0\% and cycle II by $95 \%$ means there is an improvement of 95\%. Achievement in the second cycle has exceeded the predetermined success indicators which are equal to $75 \%$. Based on the results of the research, it can be concluded that the big book media can improve the speaking ability of children aged 5-6 years. The increase occurred, because in storytelling using a big book that had never been applied at the school, the special characteristics of the big book were colourful, interesting images, and words that could be repeated, had predictable plots.

Keywords: Speaking, the Big book Media, Children Aged 5-6 Years. 


\section{PENDAHULUAN}

$\mathrm{P}$ endidikan anak usia dini (PAUD) adalah upaya untuk menstimulasi, membimbing, mengasuh, dan pemberian kegiatan pembelajaran yang akan menghasilkan kemampuan dan keterampilan anak. Berdasarkan UU Nomor 20 Tahun 2003 tersebut, rentang anak usia dini dari lahir sampai usia enam tahun adalah usia kritis sekaligus strategis dalam proses pendidikan dan dapat mempengaruhi proses serta hasil pendidikan seseorang selanjutnya. Artinya pada periode ini merupakan periode yang mendukung untuk menumbuh kembangkan berbagai kemampuan, kecerdasan, bakat, kemampuan fisik, kognitif, sosial - emosional dan spritual, termasuk Bahasa. Bahasa merupakan aspek yang sangat penting dalam kehidupan manusia. bahasa juga memberikan peranan penting dalam perkembangan anak. Dengan menggunakan bahasa, anak akan tumbuh dan berkembang menjadi manusia dewasa yang dapat bergaul di tengah-tengah masyarakat. Periode paling sensitif terhadap kemampuan berbahasa dalam kehidupan seseorang adalah antara umur 0-8 tahun. Kemampuan bahasa tidak hanya ditunjukkan oleh kemampuan membaca, tetapi juga kemampuan yang lain seperti, penguasaan kosakata, pemahaman, dan berkomunikasi. Menurut Broemly \& Dhieni, (2007) Kegiatan-kegiatan yang dapat dilakukan dalam mengembangkan kemampuan berbahasa adalah kegiatan yang dapat menstimulasi kemampuan mendengarkan, berbicara dan menulis merupakan kebutuhan yang penting dimiliki oleh setiap anak agar dapat diterima oleh lingkungannya.

Menurut Musfiroh (2010), bahasa mencakup setiap sarana komunikasi dengan menyimbolkan pikiran dan perasaan untuk menyampaikan makna kepada orang lain. Sedangkan menurut Mulyati (2015) bahasa merupakan alat komunikasi yang berupa sistem lambang bunyi yang dihasilkan alat ucap manusia. Bahasa terdiri atas kata-kata atau kumpulan kata. Bahasa dapat diartikan sebagai alat untuk menyampaikan sesuatu yang terlintas di dalam hati atau alat untuk untuk berinteraksi atau alat untuk berkomunikasi dalam arti alat untuk menyampaikan pikiran, gagasan, konsep atau perasaan.Anak secara alami belajar bahasa dari interaksinya dengan orang lain untuk berkomunikasi, yaitu menyatakan pikiran, keinginannya, memahami pikiran dan keinginan orang lain. Oleh karena itu belajar bahasa yang paling efektif ialah dengan bergaul dan berkomunikasi dengan orang lain.

Serupa dengan pendapat Montessori dalam Suyadi (2010), ketika anak "belajar" bahasa melalui interaksi orang dewasa, anak-anak tidak hanya "mempelajari" redaksi kata dan kalimat, melainkan juga struktur kata dan kalimat itu sendiri. Pola perkembangan bahasa anak sebagian besar hanya bisa diperoleh anak melalui interaksi, percakapan maupun dialog dengan orang dewasa. Aktivitas inilah yang dapat membuat anak memperoleh model berbahasa, memperluas pengertian, mencakup kosakata yang ekspresif dan menjadi motivasi anak-anak dalam berinteraksi dengan orang lain atau kehidupan sosial. Pengembangan bahasa yang terbaik adalah ketika anak-anak bertindak sebagai rekan percakapan dan masuk ke dalam pembicaraan atau dialog yang sebenarnya. Bahasa merupakan sarana yang sangat penting dalam kehidupan anak maka perlu dikembangkan pada anak didik sejak usia Taman Kanak-Kanak.

Selanjutnya dalam mengembangkan kemampuan berbahasa, anak memerlukan orang dewasa yang memberi stimulasi, baik di rumah, sekolah maupun lingkungan sekitarnya. Orang dewasa yang memiliki peran paling utama dan pertama adalah orang tua, terutama ibu. Orang tua memiliki peran yang sangat penting dalam setiap tahap perkembangan bahasa anak. Ketika anak memasuki usia TK, perkembangan bahasanya belum sempurna. Orang tua masih memiliki keterbatasan dalam pengalaman dan pemahaman tentang dunia di sekitarnya. Mereka membutuhkan suatu kesempatan untuk bisa berbicara, serta berdiskusi. Karena itu, guru sebagai fasilitator sebaiknya menyusun pembelajaran yang memberikan stimulasi perkembangan bahasa anak seperti diskusi, cerita yang kreatif, film, dsb.

Peran guru dan orang tua sangat penting dalam perkembangan bahasa anak. Guru harus kreatif dalam menstimulasi kemampuan bahasa anak, dimana metode yang digunakan disesuaikan dengan karakter dan kebutuhan tiap anak Sehingga dapat dicapai kemampuan berbahasa yang baik, yang kemudian dilanjutkan dengan kemampuan membaca dan menulis pada anak. Kemampuan bahasa terdiri dari dua yaitu Bahasa reseptif dan Bahasa ekspresif. Menurut (Teresa \& Jeanne, 2004), bahasa reseptif adalah kemampuan untuk memahami apa yang didengar (menyimak), dan dibaca (membaca) seseorang yang melibatkan pemahaman bahasa. Bahasa ekspresif adalah 
kemampuan untuk mengkomunikasikan secara efektif baik dalam bentuk lisan (berbicara) ataupun tulisan (menulis). Peraturan Menteri Pendidikan dan Kebudayaan Republik Indonesia Nomor 146 Tahun 2014 Tentang Kurikulum 2013 Pendidikan Anak Usia Dini menjelaskan bahwa bahasa ekspresif mencapai puncaknya ketika anak mulai berusia 5-6 tahun, anak sudah mulai mengungkapkan keinginan, perasaan, dan pendapat dengan kalimat sederhana dalam berkomunikasi dengan anak atau orang dewasa, mengungkapkan perasaan, ide dengan pilihan kata yang sesuai ketika berkomunikasi, menceritakan kembali isi cerita secara sederhana. Pengungkapan dan pemahaman bahasa ekspresif pada taman kanak-kanak ditunjukkan melalui keterampilan bercerita. Kompetensi dasar dalam berbahasa ekspresif terdiri dari kemampuan anak menunjuk ke sesuatu yang diinginkan, imitasi kata, melabel, membuat pilihan dan mengatakan apa yang diinginkan secara verbal.

Jadi bahasa reseptif dapat berkembang melalui proses penglihatan dan pengalaman. Berkembangnya bahasa reseptif akan mempengaruhi perkembangan bahasa ekspresif, dimana bahasa ekspresif dikembangkan melalui pengalaman yang di peroleh lalu di ekspresikan melalui proses berbicara.

Berdasarkan UU No 137 Tahun 2013 tentang Standar Nasional Pendidikan Anak Usia Dini (STTPA) bahwa aspek perkembangan bahasa anak usia 5-6 tahun terdiri dari: 1. Memahami bahasa dengan indikator: a. Mengerti beberapa perintah secara bersamaan, b. Mengulang kalimat yang lebih kompleks, c. Memahami aturan dalam suatu permainan, d. Senang dan menghargai bacaan. 2 . Mengungkapkan bahasa dengan indikator: a. Menjawab pertanyaan yang lebih kompleks, $b$. Menyebutkan kelompok gambar yang memiliki bunyi yang sama, c. Berkomunikasi secara lisan, memiliki perbendaharaan kata, serta mengenal simbol-simbol untuk persiapan membaca, menulis, dan berhitung, d. Menyusun kalimat sederhana dalam struktur lengkap (pokok kalimat-predikatketerangan), e. Memiliki lebih banyak kata-kata untuk mengekpresikan ide orang lain, melanjutkansebagian cerita/dongeng yang telah diperdengarkan, menunjukkan pemahaman konsep-konsep dalam buku cerita. 3. Keaksaraan dengan indikator: a. Menyebutkan simbol-simbol huruf yang dikenal, b. Mengenal suara huruf awal dari nama benda-benda yang ada di sekitarnya, c. Menyebutkan kelompok gambar yang memiliki bunyi ./ huruf awal yang sama, d. Memahami hubungan antara bunyi dan bentuk huruf.

Kemampuan perkembangan berbicara anak mampu menambah kosakata secara mandiri dalam bentuk komunikasi yang baik. Karakteristik perkembangan kemampuan berbicara anak usia 56 tahun adalah anak sudah menguasai kosa kata 2500 kosakata, mengucapkan kalimat lima sampai tujuh kata, mengucapkan kalimat- kalimat yang hampir dapat dimengerti secara keseluruhan, dapat bercakap-cakap seperti orang dewasa, menggunakan bentuk kata kerja dan urutan kata serta struktur kalimat yang tepat (Allen dan Marotz, 2010). Perkembangan pada periode ini penggunaan kosakata merupakan landasan bagi anak untuk mengembangkan kemampuan berbahasa, khusunya kemampuan berbicara.

Bila dicermati kemampuan berbicara pada anak usia dini tersebut di atas, diketahui bahwa anak telah mulai dilatih untuk berbicara atau berkomunikasi agar mereka dapat berinteraksi dengan yang lainnya. Melalui kemampuan ini anak dapat menyampaikan pesan-pesan atau menerima pesan dari orang lain. Sehubungan dengan penelitian ini, maka kemampuan berbicara hanya dibatasi pada aspek-aspek tertentu saja, yaitu: berbicara lancar dengan kalimat sederhana, berbicara dengan kata ganti aku atau saya, mampu menjawab pertanyaan secara sederhana.

\section{Pengertian Kemampuan Berbicara}

Menurut Kamus Besar Bahasa Indonesia, kemampuan berasal dari kata mampu yang berarti kuasa, bias, atau sanggup melakukan sesuatu. Sedangkan Robbins dan Judge (2008), kemampuan (ability) adalah kapasitas seseorang individu untuk melakukan beragam tugas dalam suatu pekerjaan. Tidak semua manusia yang diciptakan memiliki kemampuan yang sama tidak berarti bahwa beberapa individu dianggap lebih rendah dari individu yang lain. Walaupun setiap individu memiliki kemampuan yang dimilikinya dapat meningkatkan kemungkinan seseorang melakukan tugasnya dengan baik.

Definisi lebih lanjut mengenai definisi kemampuan, menurut Wortham (2005), "ability refers to the current level knowledge or skill in a particular area". Kemampuan mengacu pada tahap pengetahuan atau keterampilan dalam bidang tertentu. Aspek perkembangan pada diri seseorang bisa menjadi suatu kemampuan jika aspek perkembangan tersebut dilatih. 
Kemampuan adalah keterampilan yang dimiliki seseorang dalam suatu bidang tertentu. Masingmasing individu memiliki kemampuan dalam bidang tertentu yang dapat diungguli dari dirinya dan tidak semuanya sama. Dalam ini penting untuk mengetahui aspek-aspek perkembangan apa yang sekiranya terlihat menonjol pada diri seseorang. Aspek perkembangan bahasa anak merupakan salah satu dari beberapa aspek lainnya. Anak akan terampil berbahasa jika telah memiliki kemampuan dengan melatihnya dan memberikan stimulus yang tepat. Kemampuan dalam bidang bahasa mencakup empat aspek, yaitu kemampuan menyimak, membaca, menulis dan berbicara.

Berbicara merupakan salah satu dari bagian bentuk bahasa dalam berkomunikasi. Menurut Hurlock (2001), bicara adalah bentuk bahasa yang menggunakan artikulasi atau kata-kata yang digunakan untuk menyampaikan maksud. Sejalan dengan, Tarigan (2013) mengemukakan bahwa berbicara merupakan kemampuan mengucapkan bunyi-bunyi artikulasi atau kata-kata untuk mengekspresikan, menyatakan atau menyampaikan pikiran, gagasan, dan perasaan. Kemudian tujuan utama dari berbicara adalah untuk berkomunikasi.

Menurut Zainatuddar (2015) menjelaskan bahwa berbicara adalah sebuah proses penyampaian maksud kepada orang lain dalam berbagai konteks. Komunikasi yang dilakukan anak akan membangun hubungan sosial yang baik dengan temannya. Lingkungan menjadi hal penting untuk mengembangkan kemampuan berbicara, yakni peran teman sebaya serta hubungan antara orangtua dan anak.

Menurut Soenjono (2005) menambahkan bahwa ujaran yang ideal memiliki rangkaian kata-kata yang terangkai dengan rapi dan diujarkan dalam rangkaian yang tidak terputus-putus, anak usia 5-6 tahun telah mampu menyusun kalimat yang lebih kompleks yang terdiri atas semua unsur kalimat. Anak juga dapat membuat kalimat yang terdiri atas beberapa anak kalimat dan mampu berbicara dengan 6 - 8 kata perkalimat. Anak mengetahui bagaimana caranya berbicara agar apa yang disampaikanya dapat dimengerti orang lain.Selanjutnya Hurlock dalam Dhieni (2006) mengemukakan tiga kriteria untuk mengetahui tingkat kemampuan berbicara anak yaitu:

1. Anak mengetahui arti kata yang digunakan dan mampu menghubungkan dengan objek yang diwakilinya.
2. Anak mampu melafalkan kata-kata yang dapat dipahami orang lain dengan mudah.

3. Anak memahami kata-kata tersebut bukan karena telah sering mendengar atau mendugaduga.

Bedasarkan pendapat di atas, ketika seseorang ingin menyampaikan keinginan dan perasaannya, artikulasi atau kata-kata yang diucapkan harus jelas sehingga dapat dimengerti oleh orang lain. Orang lain yang menjadi lawan bicara pada saat itu akan paham maksud dan tujuan yang ingin disampaikan. Sehingga dapat dikatakan kemampuan berbicara ialah salah satu keterampilan berbahasa dalam kehidupan seharihari khususnya pada aspek berbicara. Apabila seseorang memiliki kemampuan berbicara yang baik, maka orang yang menjadi pasangan bicara akan paham dengan apa yang dibicarakan.

\section{Aspek-aspek Berbicara Anak}

Bahasa terdiri dari kata-kata yang digunakan dan memiliki aturan untuk menyusun berbagai variasi dan mengkombinasikannya. Menurut Gleason (dalam Santrock, 2007) terdapat lima sistem aturan bahasa, yaitu fonologi, morfologi, sintakis, semantik dan pragmatik. Berikut uraian mengenai lima sistem aturan bahasa: a. Fonologi, b. Morfologi, c. Sintakis, d. Semantik, dan e. Pragmatik.

Secara naluriah, anak memiliki potensi untuk berkomunikasi dengan lingkungan yang telah diwujudkan sejak lahir. Ketika anak-anak mempelajari bahasa, mereka sedang mengembangkan lima aspek bahasa yang telah disebutkan diatas. Kelima aspek bahasa tersebut akan berkembang seiring dengan pemerolehan bahasa anak. Aspek-aspek berbicara sangat mempengaruhi kemampuan seorang anak untuk menyampaikan gagasan dan pendapat serta dapat memahami kata yang diucapkan maka dari itu ketika anak mampu menguasai berbagai aspek berbicara, maka dengan mudah anak mengembangkan keterampilan berbicaranya.

Kemampuan yang dikembangkan dalam berbicara menurut Barzun (2009) adalah ucapan, lafal, mengingat, diksi (pilihan kata), frasa, struktur kalimat, tata bahasa, ketepatan, kelancaran, bagaimana bertanya dan menjawab pertanyaan, bagaimana menggambarkan suatu adegan, menjelaskan sebuah proses, bercerita bagaimana membantah, berdebat, berdiskusi secara cerdas dan 
berpidato. Sedangkan Hurlock (dalam Susanto, 2017), mendeskripsikan tugas dalam belajar bicara pada masa awal kanak-kanak sebagai berikut :

1. Pengucapan kata-kata, anak sulit belajar mengucapkan bunyi tertentu dan kombinasi bunyi.

2. Menambah kosa kata, kosa kata anak meningkat pesat ketika belajar kata-kata baru dan arti baru untuk kata lama.

3. Membentuk kalimat, kalimat biasanya terdiri dari tiga atau empat kata, hal ini sudah mulai disusun anak pada usia dua atau tiga tahun. Kalimat ini banyak tidak lengkap terutama dari kata benda dan kata kerja, kata depan dan kata penghubung, dan sesudah tiga tahun anak membentuk kalimat yang terdiri dari enam sampai delapan kata.

Bedasarkan dari penjelasan di atas secara keseluruhan terdapat lima sistem aturan bahasa yaitu fonologi, morfologi, sintakis, semantik, dan pragmatik. Kelima aspek bahasa tersebut akan berkembang seiring dengan pemerolehan bahasa anak. Sedangkan hal-hal umum yang perlu diperhatikan dalam kemampuan berbicara adalah pelafalan, pemilihan kata, tata bahasa, dan kelancaran. Hal ini dapat terlihat bagaimana seseorang bertanya, menjawab pertanyaan, menggambarkan suatu adegan, menjelaskan sebuah proses, bercerita, membantah, berdebat, berdiskusi, dan berpidato. Namun, lingkup perkembangan dalam berbicara untuk anak usia dini hanya tiga yaitu pengucapan kata, penambahan kosa kata, dan membentuk kalimat.

\section{Karateristik Kemampuan Berbicara Anak 5-6 Tahun}

Menurut Peraturan Menteri Pendidikan dan Kebudayaan RI Nomor 137 Tahun 2013 (Kemendikbud, 2015) terdapat tiga kategori dalam lingkup perkembangan bahasa anak yaitu, memahami bahasa, mengungkapkan bahasa, dan keaksaraan. Berikut uraian tingkat pencapaian perkembangan bahasa anak dari ketiga kategori tersebut khususnya pada anak usia 5 - 6 tahun ialah:

1. Memahami Bahasa dengan indikator: a. Mengerti beberapa perintah secara bersamaan, b. Mengulang kalimat yang lebih kompleks, c. Memahami aturan dalam suatu permainan, dan d. Senang dan menghargai bacaan.

2. Mengungkapkan Bahasa dengan indikator: a. Menjawab pertanyaan yang lebih kompleks, $b$.
Menyebutkan kelompok gambar yang memiliki bunyi yang sama, c. Berkomunikasi secara lisan, memiliki perbendaharaan kata, serta mengenal simbol-simbol untuk persiapan membaca, menulis, dan berhitung, $d$. Menyusun kalimat sederhana dalam struktur lengkap (pokok kalimat-predikat-keterangan), e. Memiliki lebih banyak kata-kata untuk mengekpresikan ide orang lain, dan $\mathrm{f}$. melanjutkan sebagian cerita/dongeng yang telah diperdengarkan, g. menunjukkan pemahaman konsep-konsep dalam buku cerita.

3. Keaksaraan dengan indikator: a. Menyebutkan simbol - simbol huruf yang dikenal, b. Mengenal suara huruf awal dari nama bendabenda yang ada di sekitarnya, c. Menyebutkan kelompok gambar yang memiliki bunyi ./ huruf awal yang sama, d. Memahami hubungan antara bunyi dan bentuk huruf, e. membaca nama sendiri, dan $f$. memahami arti kata dalam cerita.

Selanjutnya dituliskan dalam Peraturan Menteri Pendidikan dan Kebudayaan RI No 146 Tahun 2014 Tentang Kurikulum 2013 Pendidikan anak Usia Dini (2015) diketahui terdapat kompetensi dasar dalam kemampuan berbahasa, yaitu (KD 3.11) memahami bahasa ekspresif dan (KD 4.11) menunjukkan kemampuan berbahasa ekspresif (mengungkapkan bahasa secara verbal dan non verbal). Berikut uraian indikator pencapaian khususnya pada perkembangan Bahasa ekspresif pada anak usia $5-6$ tahun ialah:

1. Mengungkapkan keinginan, perasaan dan pendapat dengan kalimat sederhana dalam berkomunikasi dengan anak atau orang dewasa.

2. Menunjukkan perilaku senang membaca buku terhadap buku-buku yang dikenali.

3. Mengungkapkan perasaan ide dengan pilihan kata sesuai ketika berkomunikasi.

4. Menceritakan kembali isi cerita secara sederhana.

Kemampuan komunikatif anak-anak sendiri meliputi bahasa reseptif dan ekspresif. Menurut McDevitt dan Ormord (2004), bahasa reseptif adalah kemampuan untuk memahami apa yang didengar, dan dibaca seseorang yang melibatkan pemahaman bahasa. Bahasa ekspresif adalah kemampuan untuk mengkomunikasikan secara efektif baik dalam bentuk lisan ataupun tulisan. Hal ini menjelaskan bahwa bahasa reseptif merupakan pemahaman anak mengenai kata-kata yang diengar melalui menyimak dan dilihat 
melalui membaca. Sedangkan bahasa ekspresif melibatkan kemampuan dalam memproduksi katakata melalui bunyi (berbicara) atau tulisan (menulis).

Menurut Fidesrinur (2009) tahapan perkembangan berbahasa anak usia dini yang mana kemampuan berbicara anak yang akan berkembang melalui kemampuannya dalam menyimak dan menirukan dengan ucapan bentuk bunyi-bunyi yang masih terbatas sesuai dengan usianya. Hal ini sejalan dengan Tarigan (2012) bahwa berbicara adalah suatu keterampilan berbahasa yang berkembang pada kehidupan anak yang hanya didahului oleh keterampilan menyimak, dan pada masa itulah kemamuan berbicara dipelajari.

Bedasarkan hal itu, maka dapat disimpulkan bahwa kemampuan berbicara merupakan daya atau upaya yang dimiliki anak untuk mengucapkan bunyi-bunyi artikulasi untuk mengungkapkan, mengekspresikan dan mengkomunikasikan gagasan dan perasaan ke dalam bentuk bahasa atau lisan agar dapat dipahami orang lain disertai dengan lafal yang tepat, struktur kalimat sederhana dan penggunaan kosakata yang dipahami orang lain. Sejalan dengan Standar Tingkat Pencapaian Perkembangan Anak (STTPA), mengungkapkan bahasa dengan indikator: a) Menjawab pertanyaan yang lebih kompleks, b) Menyebutkan kelompok gambar yang memiliki bunyi yang sama, c) Berkomunikasi secara lisan, memiliki perbendaharaan kata, serta mengenal simbolsimbol untuk persiapan membaca, menulis, dan berhitung, d) Menyusun kalimat sederhana dalam struktur lengkap (pokok kalimat-predikatketerangan), e) Memiliki lebih banyak kata-kata untuk mengekpresikan ide orang lain, f) melanjutkan sebagian cerita/dongeng yang telah diperdengarkan, g) menunjukkan pemahaman konsep-konsep dalam buku cerita.

\section{Pengertian Metode Bercerita}

Metode bercerita merupakan sebuah metode yang banyak digunakan oleh para guru untuk menunjang proses pembelajaran. Guru yang baik adalah guru yang dapat memberikan pembelajaran yang menyenangkan dan sesuai dengan karakteristik anak.

Menurut Irwanto (2016), metode bercerita adalah suatu pembelajaran yang disampaikan dengan bercerita. Pendapat lain dikemukakan oleh Yaumi (2013) yang menyatakan story-telling atau metode bercerita adalah suatu cara menyampaikan atau menguraikan suatu peristiwa atau kejadian melalui kata, gambar, atau suara yang diberikan beberapa penambahan improvisasi dari pencerita sehingga dapat memperindah jalannya cerita. Guru harus mampu membawakan cerita dengan baik dan menarik. Hal ini akan sangat membantu kelancaran proses serta tujuan pembelajaran. Guru yang tidak mampu membawakan cerita dengan baik akan kehilangan kesempatan untuk menyampaikan tujuan pembelajaran.

Dhieni (2008) menyatakan bahwa metode bercerita adalah cara penyampaian atau penyajian materi pembelajaran secara lisan dalam bentuk cerita dari guru kepada anak didik. Melalui bercerita yang disajikan oleh guru, anak-anak akan dapat mengembangkan seluruh aspek perkembangannya dan kompetensi dasar yang harus dicapai oleh anak baik dalam aspek kognitif, sosial emosional, fisik motorik dan bahasa. Rahmawati (2017) memamparkan bahwa metode bercerita adalah kegiatan pembelajaran yang diberikan kepada anak dengan cerita kemudian anak mengulang kembali ceritatersebut menggunakan bahasanya sendiri. Melalui metode bercerita anak akan mendapatkanpengetahuan dan pengalaman dari cerita yang disampaikan pada anak secara lisan.

Selain itu bercerita merupakan kegiatan yang sangat menarik dan menyenangkan bagi anak. Oleh karena itu bercerita sangat baik untuk diterapkan pada anak usia dini. Cerita akan menyenangkan anak-anak sebagai peminatnya. Anak akan tertawa lepas ketika mendengar hal-hal yang lucu dari cerita yang dibawakan guru. Selain itu banyak nasehat-nasehat yang akan dapat mengembangkan kecerdesan moral maupun sosial emosionalnya. Melalui cerita akan terbentuk pola perilaku yang baik tanpa menyakiti hati anak-anak atau bahkan memarahi anak.

\section{Karakteristik Big book}

Big book merupakan sebuah media yang memiliki karakteristik khusus yang dibesarkan, baik teks maupun gambarnya, serta memiliki karakteristik khusus dalam segi bentuk gambar, warna. Agar dalam proses pembelajaran, di dalamnya terjadi kegiatan membaca bersama (shared reading) antara guru dan murid menurut Madyawati (2016). Buku ini mempunyai karakteristik khusus yang penuh warna-warni, gambar yang menarik, maupun kata yang dapat diulang-ulang, mempunyai plot yang mudah ditebak, dan 
memiliki pola teks yang berirama untuk dapat di nyanyikan. Menurut Madyawati (2016) menyatakan bahwa big book memungkinkan siswa belajar membaca melalui cara mengingat dan megulang bacaan. Sejalan dengan Usaid (2014), media big book merupakan buku jenis bacaan yang di dalamnya terdapat gambar, tulisan, ataupun ukuran dalam skala besar. Ukuran media big book bervariasi, mulai dari A3, A4, A5 maupun dapat menyesuaikan berdasarkan besar kecilnya kelas yang diajarkan.

Big book mempunyai ciri-ciri atau karakteristik yang merupakan keutamaan dari Big book itu sendiri sehingga sangat tepat untuk digunakan oleh para guru untuk mengajarkan bahasa pada guru untuk mengajarkan bahasa pada semua aspeknya, baik pada aspek menyimak, membaca, menulis dan berbicara. Menurut Solehuddin (2008) karakteristik Big book adalah sebagai berikut: 1 . pola pengulangan, 2. pola pengulangan kamulatif, 3. irama (seperti irama bayi Inursery I Rhymes), 4. pola bacaan bedasarkan pada budaya yang dikenal oleh anak, dan 5. alur cerita yang mudah ditebak.

\section{METODE PENELITIAN}

Sesuai dengan tujuan penelitian ini yaitu untuk meningkatkan kemampuan berbicara anak melalui media Big book untuk anak usia 5-6 tahun. Maka jenis penelitian yang akan digunakan adalah Penelitian Tindakan Kelas (PTK).

\section{Desain Penelitian}

Penelitian ini menggunakan metode penelitian tindakan kelas. Penelitian Tindakan Kelas sifatnya berbasis kelas yang melibatkan komponen yang ada di dalamnya. Penelitian ini merupakan salah satu cara guru untuk memperbaiki dan meningkatkan mutu pembelajaran dikelas. Penelitian dilakukan melalui empat tahap yaitu perencanaan tindakan, observasi, dan refleksi. Secara keseluruhan, empat tahapan dalam penelitian tindakan kelas membentuk suatu putaran yang disebut dengan siklus. Namun untuk menyelesaikan suatu permasalahan diperlukan lebih dari satu siklus. Pada siklus kedua penelitian akan disesuaikan dengan kebutuhan sampai dapat mencapai target yang diinginkan. Proses penelitian tindakan kelas dapat digambarkan sebagai berikut:

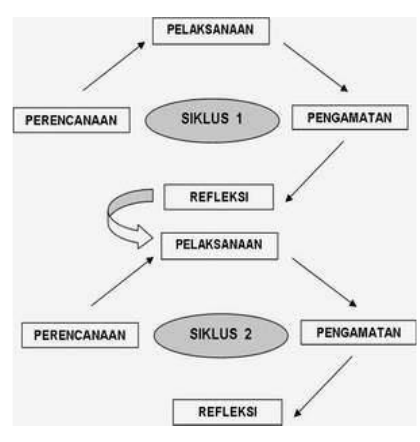

Gambar 1. Skema Kemmis \& Mc. Taggart

Penelitian ini dilaksanakan di TK Raudlatul Azhar yang terletak di Komp. Al-Azhar, Jl Sukarela 1, Kreo Selatan. Alasan penulis memilih TK Raudlatul Azhar, karena penulis mengamati terdapat suatu masalah yang terjadi di dalam kelas yaitu masih rendahnya kemampuan anak usia 5 - 6 tahun dalam meningkatkan kemampuan berbicara dan belum pernah menerapkan media big book dalam bercerita. Untuk memperoleh data peneliti membuat instrumen penelitian. Teknik pengumpulan data dari penelitian ini adalah:

\section{Observasi}

Pedoman observasi yang digunakan sebagai instrumen penelitian ini adalah lembar observasi tentang indikator pembelajaran meningkatkan kemampuan berbicara anak melalui media Big book untuk anak usia 5 - 6 tahun. Berdasarkan tahap kemampuan berbicara pada anak kelompok B (usia 5 - 6 tahun) yaitu pada saat proses pembelajaran mampu untuk berkomunikasi secara lisan, menyusun kalimat sederhana secara terstruktur (S.P.O.K), dan melanjutkan sebagian cerita dengan memberi check list. Selain itu, dalam penelitian ini peneliti juga menggunakan lembar observasi guru dan anak untuk mengamati aktivitas guru dan anak selama proses KBM.

\section{Dokumentasi}

Dokumentasi berfungsi sebagai bukti penelitian yang telah dilakukan peneliti pada TK B Raudlatul Azhar, Kereo Selatan. Adapun kegiatan yang di dokumentasi menggunakan kamera handphone pada saat kegiatan pembelajaran, RPPH dan RPPM.

Teknik analisis data dalam penelitian ini menggunakan analisis data kualilatif. Tahapan analisis data pada penelitian ini terdiri dari tiga tahap, yaitu: Reduksi Data; Mendeskripsikan Data; dan Penyimpulan. Kriteria pada penelitian ini anak diharapkan mampu meningkatkan kemampuan berbicara, setelah melakukan pembelajaran tentang 
bercerita melalui media Big book. Penelitian ini dikatakan berhasil apabila $75 \%$ dari 25 anak mampu mencapai skor tiga pada setiap butir indikator (dalam Tampubulon, 2014). Rumus yang digunakan (dalam Anas Sudjono, 2004) sebagai berikut:

Data yang dianalisa dalam persentase menggunakan rumus:

$$
\mathrm{P}=\frac{\mathrm{F}}{\mathrm{N}} \times 100 \%
$$

Keterangan:

$\mathrm{P}=$ Angka Presentasi

$\mathrm{F}=$ Frekuensi aktivitas anak

$\mathrm{N}=$ Jumlah anak dalam satu kelas

\section{HASIL DAN PEMBAHASAN}

\section{Temuan Umum}

TK Islam Raudlatul Azhar adalah TK yang terletak di Jl. Sukarela 1, Komp al-azhar RT 02/06 Kelurahan Kreo Selatan, Kecamatan Larangan. TK Islam Raudlatul Azhar berdiri sejak tahun 1992. Sebelum didirikannya TK Islam Raudlatul Azhar, mushola Raudlatul Azhar adalah pusat kegiatan sosial dam kemasyarakatan, diantaranya kegiatan kejar paket A, Diniyyah dan Karang Balita. TK Islam Raudlatul Azhar terletak di antara mushola dan pemukiman warga.

\section{Temuan Khusus}

Penelitian Tindakan Kelas (PTK) ini dilaksanakan menjadi dua siklus, di mana masing-masing siklus terdiri dari sepuluh kali pertemuan. Indikator yang akan dinilai pada penelitian ini adalah berkomunikasi secara lisan (menceritakan kembali), menyusun kalimat sederhana secara terstruktur (S.P.O.K), dan melanjutkan sebagian cerita.

\section{Siklus I}

\section{Perencanaan}

Pada penelitian ini, peneliti bekerjasama dengan guru kelompok B2 yaitu 1 guru kelas sebagai observer dan kolabolator, peneliti sebagai observer dan fasilitator, serta teman sejawat sebagai observer dan juga membantu dalam proses pengambilan dokumentasi. Jadwal kegiatan penelitian dibuat berdasarkan kesepakatan guru dan peneliti serta disesuaikan juga dengan kalender kegiatan TK Islam Raudlatul Azhar.
Tahap perencanaan, peneliti membuat persiapan pembelajaran yang akan dilakukan pada siklus I. Peneliti mendiskusikan tema pembelajaran dan mempersiapkan Rencana Pelaksanaan Pembelajaran Harian (RPPH). Kemudian, peneliti mempersiapkan media pembelajaran yang akan digunakan dalam bercerita pada anak usia 5-6 tahun pada Kelompok B2, menyiapkan lembar observasi kemampuan bercerita, lembar observasi aktivitas guru dan anak, reward yang akan diberikan untuk memotivasi anak dan kamera handphone untuk mendokumentasikan kegiatan pembelajaran.

\section{Pelaksanaan Tindakan}

Melaksanakan tindakan sesuai dengan apa yang telah direncanakan.

\section{Observasi}

Hasil pengamatan kemampuan dalam berbicara anak melalui media big book pada siklus I diuraikan melalui tabel berikut ini:
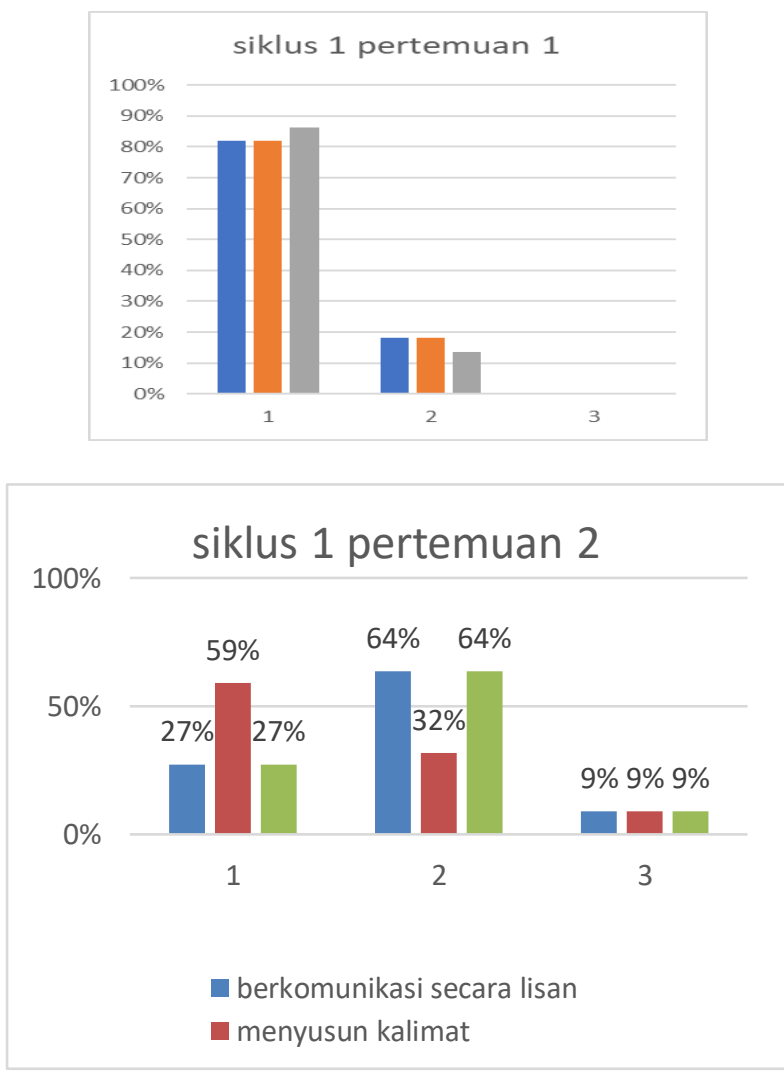

Gambar 2. Diagram Kemampuan Berbicara Anak Melalui Media Big Book 5-6 Tahun.

Selain itu, dalam penelitian ini peneliti bekerjasama dengan teman sejawat dan guru dalam 
mengisi lembar observasi aktivitas guru dan anak. Peneliti mengamati peningkatan kemampuan berbicara anak melalui media big book dan aktivitas anak dalam proses pembelajaran pada siklus I. Hasil pengamatan aktivitas guru dan anak pada saat proses pembelajaran disiklus I diuraikan melalui diagram berikut ini:

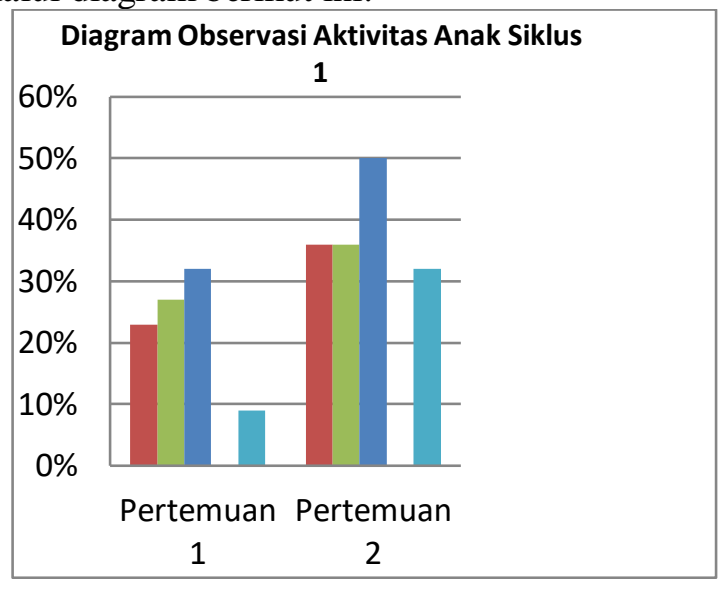

Gambar 3. Diagram Observasi Aktivitas Anak pada Siklus I

\section{Refleksi Tindakan Siklus I}

a. Menjelaskan Tujuan bercerita

Suara guru kurang lantang, sehinggaterdapat anak yang tidak mendengarkan dansesekali mengobrol dengan teman dan tidak menjelaskan apa itu tujuan guru bercerita.

b. Membacakan isi cerita

1) Pada pertemuan pertama, hari 1 sampai hari ke-5 guru menjelaskan/ bercerita sampai selesai, tetapi pada pertemuan kedua, hari 6 sampai hari ke-10 guru tidak menjelaskan sehingga anak langsung bercerita tanpa dijelaskan oleh guru.

2) Guru terlalu cepat dalam bercerita

3) Guru tidak memberikan reward kepada anak. Seharusnya guru memberikan Reward di siklus 1 ini.

\section{Siklus II}

\section{Perencanaan}

Adapun rencana perbaikan pada siklus I, adalah sebagai berikut:

a. Menjelaskan Tujuan Bercerita agar anak paham dan melantangkan suara, agar seluruh anak dapat mendengarkannya.

b. Membacakan isi cerita

Guru mengubah tempat pelaksanaan bercerita yaitu menjadi di kelas setiap anak pergantian sentra agar anak lebih kondusif ketika berada di kelas berbeda dengan guru kelas berbeda dengan memanggil 5 anak secara bergantian untuk melakukan kegiatan bercerita, sedangkan anak yang lainnya diminta tetap di dalam kelas untuk mengerjakan kegiatan lain yang telah direncanakan guru sehingga diharapkan proses pembelajaran dapat berjalan secara kondusif.

c. Guru menjelaskan kegiatan bercerita dengan perlahan-lahan atau secara detail agar anak lebih memahami cara alur cerita dan tidak ragu-ragu lagi.

d. Memberikan Reward kepada Anak

\section{Pelaksanaan Tindakan}

Melaksanakan tindakan sesuai dengan apa yang telah direncanakan.

\section{Observasi}

Observasi dilakukan peneliti ketika proses pembelajaran sedang berlangsung yaitu pada saat bercerita. Peneliti menggunakan panduan berupa lembar observasi kemampuan berbicara anak melalui media big book, baik dalam indikator berkomunikasi secara lisan (menceritakan kembali), menyusun kalimat sederhana secara terstruktur (SPOK), melanjutkan sebagian cerita. Peneliti mengamati peningkatan kemampuan berbicara anak dan aktivitas anak dalam proses pembelajaran pada siklus II. Hasil pengamatan kemampuan berbicara anak melalui media big book pada siklus II diuraikan melalui gambar berikut ini:

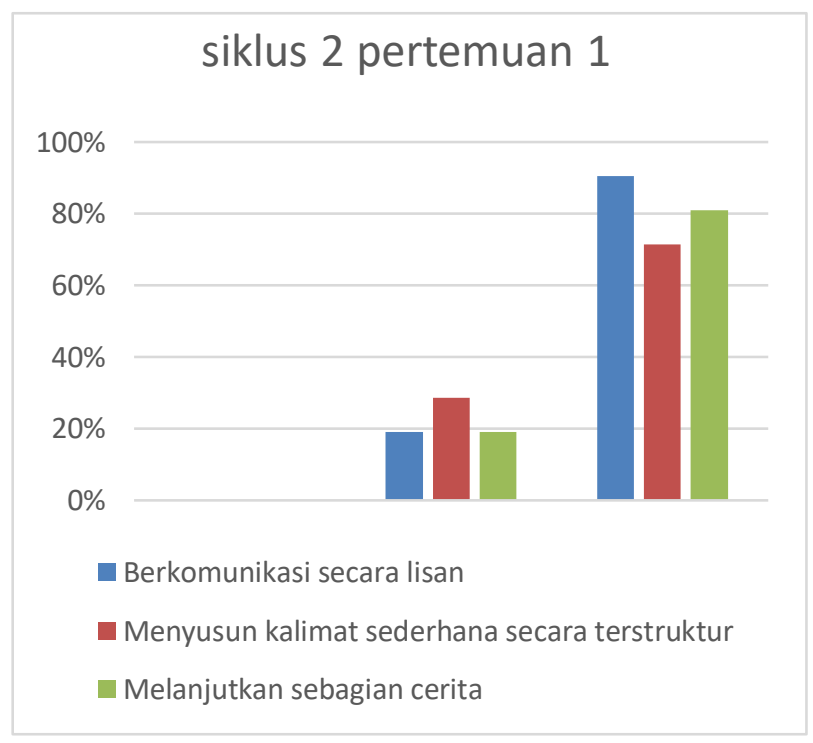

Gambar 4. Diagram Kemampuan Berbicara Anak pada Siklus II. 


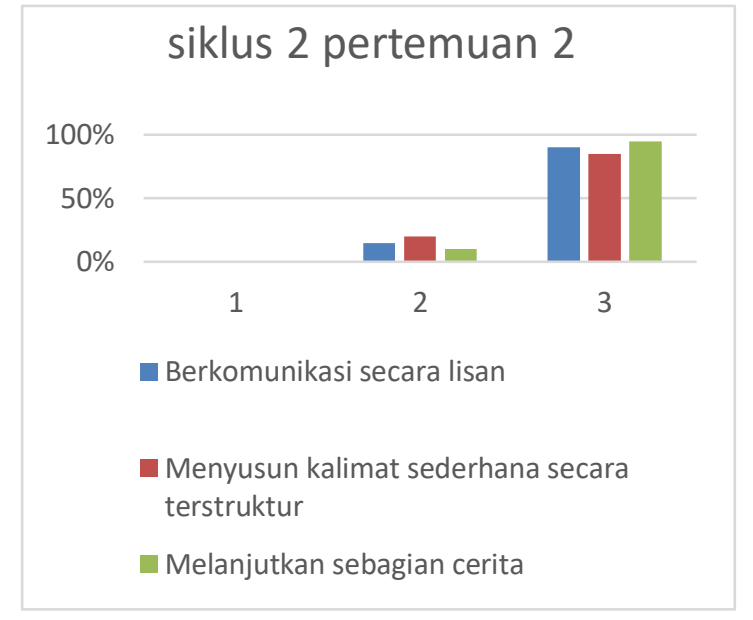

Gambar 5. Diagram Kemampuan Berbicara Anak pada Siklus II.

\section{Refleksi}

Berdasarkan hasil observasi, maka refleksi siklus II yaitu didapatkan hasil bahwa terdapat peningkatan pada aktivitas anak dan guru. Di mana pada aktivitas anak, anak terlihat sudah mulai tertib pada saat mendengarkan guru ketika menjelaskan tujuan bercerita, memperhatikan guru ketika membacakan cerita dan mau mendengar serta menjawab pertanyaan dari guru ketika evaluasi. Selain itu, ketika melakukan kegiatan bercerita anak terlihat sudah memahami dengan benar saat anak bercerita dan sesuai dengan yang telah dicontohkan oleh guru dan dengan adanya reward berupa tempat makan \& tempat minum membuat anak merasa senang. Sedangkan, pada aktivitas guru dinilai sudah terdapat peningkatan dari kelima aktivitas yang ada.

Pada siklus II, hambatan-hambatan yang terjadi disiklus I sudah banyak berkurang. Namun, masih terdapat anak yang tidak masuk. Tindakan yang peneliti lakukan pada siklus II terlihat lebih baik dibandingkan dengan tindakan siklus I.

Tindakan pada siklus II telah mencapai indikator keberhasilan penelitian, sehingga peneliti menghentikan penelitian ini pada siklus II karena sudah mencapai indikator keberhasilan yang telah ditetapkan yaitu dengan nilai rata-rata ketercapaian dalam berkomunikasi secara lisan $90 \%$, menyusun kalimat sederhana secara terstruktur $78 \%$ dan melanjutkan cerita $88 \%$. Selain itu terdapat sebagian besar anak yang sudah mampu mendapatkan skor 3, tetapi pada hari dilaksanakannya siklus II mereka tidak masuk ke sekolah, sehingga mempengaruhi nilai presentasi meningkatkan kemampuan berbicara.

Berdasarkan data yang diperoleh pada siklus II, dapat dikatakan bahwa tindakan yang dilakukan telah berhasil karena nilai yang diperoleh anak sudah melebihi target yang telah ditentukan pada indikator keberhasilan yaitu sebesar $75 \%$. Ketercapaian ini diperoleh karena mengenalkan kemampuan berbicara pada anak dilakukan dengan kegiatan bercerita, dengan media big book. Melalui bercerita anak-anak akan belajar berbicara dengan menyenangkan. Hal ini tentu saja sangat membantu anak untuk pandai berbicara. Sehingga anak mampu berbicara dengan $6-8$ kata perkalimat. Kegiatan bercerita merupakan sebuah kegiatan yang banyak digunakan oleh para guru untuk menunjang proses pembelajaran. Sebagaimana yang telah dijelaskan Moeslichatoen (2004) bercerita merupakan salah satu pemberian pengalaman belajar anak TK dengan membawakan cerita kepada anak secara lisan.

Selain itu, dalam bercerita dilakukan dengan melibatkan anak secara langsung dalam proses pembelajaran dan menggunakan media pembelajaran lainnya yang membuat kegiatan pembelajaran lebih bermakna karena sebelumnya pada proses bercerita hanya menggunakan buku cerita pada umumnya yang berukuran A4.

Sesuai dengan yang telah dijelaskan dengan Dhieni (2008) menyatakan bahwa kegiatan bercerita adalah cara penyampaian atau penyajian materi pembelajaran secara lisan dalam bentuk cerita dari guru kepada anak didik. Dalam pelaksanaan kegiatan pembelajaran di TK metode bercerita dilaksanakan dalam upaya memperkenalkan, memberikan keterangan, atau penjelasan tentang hal baru dalam rangka menyampaikan pembelajaran yang dapat mengembangkan berbagai kompetensi dasar anak. Melalui bercerita yang disajikan oleh guru, anak-anak akan dapat mengembangkan seluruh aspek perkembangannya dan kompetensi dasar yang harus dicapai oleh anak baik dalam aspek kognitif, sosial emosional, fisik motorik dan bahasa.

Kemudian, faktor lain yang mendukung meningkatkan kemampuan berbicara anak melalui media big book juga dikarenakan adanya reward yang diberikan guru sehingga membuat anak menjadi semangat dan senang dalam mengikuti kegiatan bercerita. 
Apabila dikaitkan dengan aspek perkembangan lainnya, bercerita dengan media big book bukan hanya dapat mengembangkan dan melatih perkembangan kognitif saja tetapi juga mempengaruhi aspek perkembangan lainnya yaitu seperti aspek perkembangan sosial emosional, fisik motorik, dan bahasa. Pada aspek perkembangan sosial emosional, anak dilatih untuk mengendalikan perasaan seperti bersabar, mengantri menunggu giliran, menunjukkan rasa percaya diri, memahami peraturan dan disiplin, serta menaati aturan yang berlaku. Melalui bercerita ini juga dapat melatih fisik motorik anak, baik itu motorik halus maupun motorik kasar karena yang dilakukan pada saat bercerita terdapat kegiatan meniru gerak binatang.

Selain itu, pada aspek perkembangan bahasa dapat melatih anak untuk melaksanakan kegiatan sesuai dengan arahan dan perintah sederhana yang diberikan guru serta menceritakan kembali cerita yang diceritakan oleh guru.

\section{SIMPULAN DAN SARAN}

Berdasarkan hasil data yang diperoleh dapat disimpulkan bahwa terdapat peningkatan dalam kemampuan berbicara melalui media big book ketika sebelum dan sesudah diterapkannya kegiatan bercerita pada anak usia $5-6$ tahun di TK Islam Raudlatul Azhar. Nilai peningkatan ratarata anak yang mendapat skor 3 pada setiap indikator persiklus dari siklus I ke siklus II pada indikator berkomunikasi secara lisan siklus I sebesar 0\% dan siklus II sebesar 90\% artinya terdapat peningkatan sebesar $90 \%$, pada indikator menyusun kalimat sederhana secara terstruktur siklus I sebesar $0 \%$ dan siklus II sebesar $85 \%$ artinya terdapat peningkatan sebesar $85 \%$ dan pada indikator melanjutkan sebagian cerita siklus I 0\% dan siklus II sebesar $95 \%$ artinya terdapat peningkatan sebesar $95 \%$.

Terjadinya peningkatan tersebut, dikarenakan dalam bercerita dengan menggunakan big book yang sebelumnya belum pernah diterapkan disekolah tersebut, big book karakteristik khusus yang penuh warna-warni, gambar yang menarik, maupun kata yang dapat diulang-ulang, mempunyai plot yang mudah ditebak. Jadi, anak tertarik untuk fokus terhadap guru karena big book itu sendiri sangat menarik perhatian anak. Peningkatan juga terjadi karena adanya motivasi berupa reward yang membuat anak lebih semangat dalam melakukan kegiatan hari itu.
Berdasarkan hasil penelitian tersebut, peneliti memberikan beberapa saran, diantaranya: Bagi Guru, 1). dalam melaksanakan kegiatan bercerita dengan menggunkana big book dikaitkan dengan tema pembelajaran agar anak-anak lebih paham dengan tema yang dibahas; 2). dalam mengevaluasi pembelajaran, suara guru dapat lebih lantang agar anak mau mendengarkannya; 3). Reward yang diberikan untuk anak sebaiknya lebih bervariasi seperti stiker, cap yang menark, makanan seperti biskuit, susu.

Sementara bagi kepala sekolah diharapkan Kepala sekolah dapat mendukung serta memfasilitasi dalam pembuatan media big book dan memberi arahan kepada guru-guru yang lainnya untuk kemampuan bercerita dengan menyediakan media pembelajaran yang bervariasi, misalnya big book.

\section{DAFTAR PUSTAKA}

Barzun, J. (2009). Program paedia: sebuah silabus padagogi, esai-esai karya kelompok padia. Jakarta: PT Indonesia Publishing.

Dhieni, N., et al. (2014). Metode pengembangan bahasa. Jakarta: Pusat Penerbitan Universitas Terbuka.

Fidesrinur. (2009). kemampuan berbicara anak usia dini. Jurnal Universitas Al Azhar Indonesia.

Hurlock, E. (2001). Perkembangan anak jilid 1 Edisi Keenam. Jakarta: Erlangga.

Irwanto, N. D. (2016). Kompetensi pedagogik untuk peningkatan dan penilaian kinerja guru dalam rangka implementasi kurikulum nasional. Sidoarjo: Genta GroupProduction.

Kemdikbud. (2015). Peraturan Menteri Pendidikan dan Kebudayaan Republik Indonesia Nomor 137 Tahun 2013 tentang standar nasional pendidikan anak usia dini. Jakarta: Kementerian Pendidikan dan Kebudayaan.

Kemdikbud. (2015). Peraturan Menteri Pendidikan dan Kebudayaan Republik Indonesia Nomor 146 Tahun 2014 tentang kurikulum 2013 pendidikan anak usia dini. Jakarta: Kementerian Pendidikan dan Kebudayaan.

Madyawati, L. (2016). Strategi pemgembangan bahasa. Prenada media Grup: Jakarta

McDevitt, T.M., Ormord, D., Ellis, J. (2004). Child development: educating and working with children and adolescents. New Jersey: Pearson Merll Prentice Hall.

Mulyati. (2015). Terampil berbahasa indonesia. Jakarta: Prenadamedia Group. 
Musfiroh, T. (2010). Perkembangan bahasa anak usia dini. Yogyakarta: Kementerian Pendidikan Nasional.

Rahmawati, D. (2017). Pengaruh penerapan metode bercerita terhadap keterampilan berbicara anak usia 5-6 tahun di tk dharma wanita persatuan Palas Lampung Selatan Tahun Ajaran 2016-2017.

Robbins, S.P. dan Judge, T.A. (2008). Perilaku organisasi, organizational behavior. Jakarta: Salemba Empat.

Suryadi. (2007). Cara efektif memahami perilaku anak usia dini. Jakarta: EDSA Mahkota.

Susanto, A. (2015). Perkembangan anak usia dini. Jakarta: Kencana Prenada Media Grup.
Suyadi. (2010). Panduan penelitian tindakan kelas. Jogjakarta: Diva Press.

Henry, G.T. (2013). Berbicara Sebagai Suatu Keterampilan Berbahasa. Bandung: Angkasa.

Usaid. (2014). Buku sumber untuk dosen LPTK pengembangan literasi kelas awal di LPTK. Jakarta: USAID.

Wortham, S.C. (2005). Assesment in early childhood education Fouth Edition. New Jersey: Person Education.

Yaumi, M. (2013). Prinsip-prinsip pembelajaran. Jakarta: Kencana Persada Group.

Zainatuddar. (2019). Teaching speaking in English by using the picture series technique. English Education Journal (EEJ), 6(4), 443 - 456.. 